\title{
Social Economy and Living Standards: Consumer Cooperatives in Barcelona, 1891-1935
}

\author{
Francisco J. Medina-Albaladejo ${ }^{1 \star(D)}$ and Josep Pujol-Andreu ${ }^{2}$ \\ ${ }^{1}$ Universitat de València, Departament d'Anàlisi Econòmica, Av. dels Tarongers s/n, 46022, València, \\ Spain, e-mail: francisco.medina@uv.es, and ${ }^{2}$ Universitat Autònoma de Barcelona, Spain ${ }^{1}$ \\ ${ }^{\star}$ Corresponding author
}

\begin{abstract}
The living standards of the working classes during industrialization continue to be the subject of debate in European historiography. However, other factors closely related to the institutional setting, such as the role played by social economy and the institutions for collective action, are seldom considered. This study focuses on these factors, and attempts to quantify the social impact of consumer cooperatives. We argue that these institutions substantially improved the lot of the working classes from the mid-nineteenth century onwards, helping them to increase their incomes, and access food and services, such as education and social services, which the state did not provide in sufficient measure. To demonstrate this point, we analyse thirty-five consumer cooperatives in Barcelona, an industrial centre in which these organizations were more popular than anywhere else in Spain. Our main conclusion is that consumer cooperatives increased the well-being of their members, helping them to meet their substantial calorific needs, although their diets were unbalanced and low-cost; members improved their income between five and ten per cent, by simply shopping at the institution, and gained access to basic welfare services.
\end{abstract}

\section{Introduction}

There are some important studies on the evolution of consumer cooperativism from the mid-nineteenth century onwards, but European historiography has made little progress with regard to the quantification of the social impact of these organizations. General works offer valuable insight into the evolution, social orientation, and organizational changes of cooperatives, but pay little attention to the effect of cooperatives on living standards, even in Great Britain, which is the best-known case. ${ }^{2}$ Purvis, for

\footnotetext{
${ }^{1}$ Josep Pujol-Andreu was Professor of Economic History at Universitat Autònoma de Barcelona (Spain). He died on 24 October 2019. The paper has been revised several times over the last two years. Any final errors are therefore attributable to the first author.

${ }^{2}$ J. Brazda and R. Schediwy (eds), Consumer Co-operatives in a Changing World (Geneva, 1989); E. Furlough and C. Strikwerda (eds), Consumers against Capitalism? Consumer Cooperation in Europe,

(C) The Author(s), 2021. Published by Cambridge University Press on behalf of Internationaal Instituut voor Sociale Geschiedenis. This is an Open Access article, distributed under the terms of the Creative Commons Attribution licence (https://creativecommons.org/licenses/by/4.0/), which permits unrestricted re-use, distribution, and reproduction in any medium, provided the original work is properly cited.
} 
instance, analyses the conflicts between British consumer cooperativism and shopkeepers, ${ }^{3}$ and Gurney, taking the Co-operative Wholesale Society (CWS) as a reference, focuses on the cooperatives' problems in adapting to changes in demand, the internal problems derived from their growth, and their difficult relationship with syndicalism and the labour movement. Gurney's main conclusion is that the English cooperative movement emerged weaker from the interwar period owing to its inability to adapt to new consumer preferences, the stiff competition posed by capitalist societies, and their own internal conflicts. ${ }^{4}$

Concerning food retailing, most studies deal with the issue by taking a firm-based approach: for instance, the impact of consumer cooperatives on the modernization of distribution chains and their unequal response to new forms of trade competition. Important contributions in this regard are those by Shaw and Alexander; Ekberg; Kramper; and Balnave and Patmore. ${ }^{5}$ They analyse, for different countries, aspects such as the creation of federations and the centralized buying of goods, and the development of cooperatives to improve food distribution in order to ensure the loyalty of members. Also of note are the studies by Zamagni, Battilani, and Menzani on the emergence of groups of cooperatives as umbrella organizations in Italy, ${ }^{6}$ and

North America, and Japan, 1840-1990 (Lanham, MD, 1999); M. Hilson, S. Neunsinger, and G. Patmore (eds), A Global History of Consumer Co-operation Since 1850: Movements and Businesses (Leiden, 2017); J. Birchall, The International Co-operative Movement (Manchester, 1997).

${ }^{3}$ M. Purvis, "Stocking the Store: Co-operative Retailers in North-East England and Systems of Wholesale Supply circa 1860-77”, Business History, 40:4 (1998), pp. 55-78; idem, “Crossing Urban Deserts: Consumers, Competitors, and the Protracted Birth of Metropolitan Co-operative Retailing", The International Review of Retail, Distribution and Consumer Research, 9:3 (1999), pp. 225-243; idem, "Societies of Consumers and Consumer Societies: Co-operation, Consumption, and Politics in Britain and Continental Europe c.1850-1920”, Journal of Historical Geography, 24:2 (1998), pp. 147-169.

${ }^{4}$ P.J. Gurney, “Co-operation and the 'New Consumerism' in Interwar England”, Business History, 54:6 (2012), pp. 905-924.

${ }^{5}$ G. Shaw and A. Alexander, "British Co-operative Societies as Retail Innovators: Interpreting the Early Stages of the Self-Service Revolution", Business History, 50:1 (2008), pp. 62-78; A. Alexander, "Format Development and Retail Change: Supermarket Retailing and the London Co-operative Society", Business History, 50:4 (2008), pp. 489-508; E. Ekberg, “Organization: Top Down or Bottom Up? The Organizational Development of Consumer Cooperatives, 1950-2000”, in P. Battilani and H. Schröter (eds), The Cooperative Business Movement, 1950 to the Present (Cambridge, 2012), pp. 222-242; E. Ekberg, "Confronting Three Revolutions: Western European Consumer Co-operatives and Their Divergent Development, 1950-2008”, Business History, 54:6 (2012), pp. 1004-1021; P. Kramper, "Why Cooperatives Fail: Case Studies from Europe, Japan, and the United States, 1950-2010", in Battilani and Schröter, The Cooperative Business Movement, pp. 126-149; N. Balnave and G. Patmore, "Rochdale Consumer Co-operatives in Australia: Decline and Survival”, Business History, 54:6 (2012), pp. 9861003; N. Balnave and G. Patmore, "The Outsider Consumer Co-operative: Lessons from the Community Co-operative Store (Nuriootpa), 1944-2010”, Business History, 57:8 (2015), pp. 1133-1154. See also K. Friberg et al., "The Politics of Commercial Dynamics: Cooperative Adaptations to Postwar Consumerism in the United Kingdom and Sweden, 1950-2010", in Battilani and Schröter, The Cooperative Business Movement, pp. 243-262.

${ }^{6}$ V. Zamagni, P. Battilani, and A. Casali, La cooperazione di consumo in Italia (Bologna, 2004); P. Battilani and V. Zamagni, “The Managerial Transformation of Italian Co-operative Enterprises 19462010”, Business History, 54:6 (2012), pp. 964-985; P. Battilani, “Consumer Co-operation in Italy: A Network of Co-operatives with a Multi-Class Constituency", in Hilson et al., A Global History of Consumer Co-operation since 1850, pp. 584-613; T. Menzani and V. Zamagni, "Cooperative Networks in the Italian Economy", Enterprise \& Society, 11:1 (2009), pp. 98-127. 
Hilson's analysis of the Scandinavian model for the integration of consumers and producers as a middle ground between capitalism and socialism. ${ }^{7}$

Other key aspects that have received less attention are financial, welfare, cultural, educational, and housing services provided by cooperatives, ${ }^{8}$ and the cooperatives' role in the emergence of new consumption patterns. ${ }^{9}$ There are some case studies of the above aspects, and these focus on the products distributed during different periods and in different countries. These studies examine the sort of products that consumer cooperatives sold and the impact of these on the living standards and consumption patterns of the European working classes, although no quantitative estimates are offered. ${ }^{10}$ The role of women in these institutions for collective action has also been addressed in various works. ${ }^{11}$

It is therefore necessary to try to quantify how consumer cooperatives might have contributed to improving the lot of the European working classes from the mid-nineteenth century onwards. Most consumer cooperatives in Europe followed the Rochdale model: ${ }^{12}$ they sold various products, especially food, but also carried out certain activities that had a considerable impact on the living standards of their members (for instance, providing benefits and organizing sanitary, educational, and cultural activities). ${ }^{13}$ On the eve of World War I, these organizations had nearly 25 million members, and their prestige was such that the idea of a "Co-operative

\footnotetext{
${ }^{7}$ M. Hilson, “A Consumers' International? The International Cooperative Alliance and Cooperative Internationalism, 1918-1939: A Nordic Perspective”, International Review of Social History, 56:2 (2011), pp. 203-233; idem, "Consumer Co-operation and Economic Crisis: The 1936 Roosevelt Inquiry on Co-operative Enterprise and the Emergence of the Nordic 'Middle Way"', Contemporary European History, 22:2 (2013), pp. 181-198.

${ }^{8}$ N. Robertson, "Collective Strength and Mutual Aid: Financial Provisions for Members of Co-operative Societies in Britain", Business History, 54:6 (2012), pp. 925-944; L. Samy, "Extending Home Ownership Before the First World War: The Case of the Co-operative Permanent Building Society, 1884-1913", Economic History Review, 65:1 (2012), pp. 168-193; N. Robertson, “The Business of Leisure: Sport, Labour and Co-operation in Post-War Britain”, Labor History, 55:5 (2014), pp. 638-653; M. Abbott and C. Doucouliagos, "A Long-Run Analysis of Cooperative Housing Societies and Housing Construction in Victoria, Australia”, Australian Economic History Review, 39:2 (1999), pp. 114-132; A.J.H. Jackson, “The Cooperative Movement and the Education of Working Men and Women: Provision by a Local Society in Lincoln, England, 1861-1914", International Labor and Working-Class History, 90 (2016), pp. 28-51.

${ }^{9}$ L. Black and N. Robertson, Consumerism and the Co-operative Movement in Modern British History (Manchester, 2009).

${ }^{10} \mathrm{P}$. Scholliers, "The Social-Democratic World of Consumption: The Path-Breaking Case of the Ghent Cooperative Vooruit Prior to 1914”, International Labor and Working-Class History, 55 (1999), pp. 71-91.

${ }^{11}$ B.J. Blaszak, "The Gendered Geography of the English Co-operative Movement at the Turn of the Nineteenth Century", Women's History Review, 9:3 (2000), pp. 559-583; P.J. Gurney, "Redefining 'the Woman with the Basket': The Women's Co-operative Guild and the Politics of Consumption in Britain during the Second World War", Gender and History, 32:1 (2020), pp. 189-207.

${ }^{12}$ After the principles established in Rochdale in 1844 and later adopted in the rest of Great Britain, Europe, and other parts of the world. Following Holyoake's guidelines. G.J. Holyoake, The History of the Rochdale Pioneers (London, 1857); D.C.H. Watts, "Building an Alternative Economic Network? Consumer Cooperation in Scotland from the 1870s to the 1960s", The Economic History Review, 70:1 (2017), pp. 143-170, 156; Robertson, "Collective Strength and Mutual Aid".

${ }^{13}$ Holyoake, The History of the Rochdale Pioneers.
} 
Commonwealth" was floated as an alternative to individualistic capitalism. ${ }^{14}$ These organizations have been analysed from different perspectives, but their impact on the living standards of the working classes has been somewhat neglected. Currently, some scholars, such as Watts, regard them as the most successful worker-led alternative to capitalism. ${ }^{15}$

This work aims to improve our understanding of the factors that might have contributed to an improvement in living standards in Europe from the mid-nineteenth century onwards, with a focus on the social economy and the activities undertaken by consumer cooperatives. We shall quantify their social impact by examining the data pertaining to a number of them, especially in Barcelona, ${ }^{16}$ an industrial centre in which these organizations were more popular than anywhere else in Spain. Barcelona was the powerhouse of the Spanish textile industry, accounting for over eighty per cent of the sector in the early twentieth century. ${ }^{17}$ In fact, the province was the country's leading industrial centre, and 58.6 per cent of its working population was engaged in industrial production in 1930, compared to 27.2 per cent at the national level. ${ }^{18}$ In that year, 74.2 per cent of the province's population was urban in nature, compared with a national average of 37.1 per cent, and its capital was the most populous city in the country, with nearly one million inhabitants. ${ }^{19}$ As such, Barcelona was Spain's main urban centre, comparable with other European urban areas in which consumer cooperativism also underwent substantial growth. Barcelona is therefore representative of other industrial areas in Spain $^{20}$ and Europe, with an organized working class used to develop collective action institutions with which to address the social consequences of industrialization. This case study will enable us to present a few hypotheses and results that can be of application in other European industrial regions, especially concerning the role played by the social economy in the living standards of the working classes during industrialization.

We shall try to move further using the data from thirty-five consumption cooperatives in Barcelona (30) and the nearby province of Girona (5) between 1890 and 1935 (see Table A1, Appendix). ${ }^{21}$ In Spain, consumer cooperatives developed slowly, but Barcelona was something of an exception. Between 1910 and 1915, barely one per

\footnotetext{
${ }^{14}$ T.W. Mercer, Towards the Co-operative Commonwealth (Manchester, 1936); J. Murray Luck, The War on Malnutrition and Poverty (New York, 1946); Watts, "Building an Alternative Economic Network?", p. 167.

${ }^{15}$ Watts, "Building an Alternative Economic Network?", p. 167.

${ }^{16}$ Sources and data for thirty-five consumer cooperatives have been examined, most of them from Barcelona and a few from the nearby province of Girona (see Table Al, Appendix).

${ }^{17}$ A. Carreras, "Industria", in A. Carreras and X. Tafunell (eds), Estadísticas históricas de España (Bilbao, 2005), pp. 357-453, 401.

${ }^{18}$ F.J. Beltrán Tapia and J. Martinez-Galarraga, "Inequality and Growth in a Developing Economy: Evidence from Regional Data (Spain, 1860-1930)", Social Science History, 44:1 (2020), pp. 169-192, 173.

${ }^{19} \mathrm{X}$. Tafunell, "Urbanización y vivienda", in Carreras and Tafunell, Estadísticas históricas de España, pp. 455-499, 487-489.

${ }^{20}$ The most significant Spanish region in this regard is the Basque Country, which witnessed the emergence of important consumer cooperatives in the framework of the development of major steelworks.

${ }^{21}$ For a preliminary approximation, see F.J. Medina-Albaladejo and J. Pujol-Andreu, "Cooperativas de consumo y niveles de vida, España 1865-1939. Una primera aproximación”, Scripta Nova, 18 (2014); F.J. Medina-Albaladejo, "Consumer Co-operatives in Spain, 1860-2010", in Hilson et al., A Global History of Consumer Co-operation since 1850, pp. 326-352.
} 
cent of Spaniards benefited from these cooperatives, while in Catalonia they reached nearly ten per cent of the population, and as much as forty per cent in some municipalities (Palafrugell, Sant Feliu de Guixols). ${ }^{22}$ It is also likely that their reach grew even more in later years, given that, in some municipalities in the province of Barcelona (Manlleu, Sant Vicenç de Torelló, Roda de Ter, Santa María de Corcó, and Rubí), consumer cooperatives reached between twenty and thirty-five per cent of the population between 1924 and $1935 .^{23}$

The text is divided into four sections, the first of which deals with the evolution of consumer cooperativism in Europe between the mid-nineteenth century and World War II. The following two sections focus on consumer cooperatives in Barcelona and suggest three indicators to gauge their impact on living standards: food supply and nutrition; living costs; and cultural, economic, and welfare activities.

\section{Consumer cooperatives in Europe: Historical background}

One of the most significant actions by the European labour movement in the midnineteenth century was to create consumer cooperatives. This does not mean that these institutions were always organized by labour organizations, or that they were always successful. Like workers' mutual insurance organizations, consumer cooperativism was most intense in industrialized urban regions, and the impulse behind the creation of cooperatives, at least at the beginning, came in the form of reformist members of the bourgeoisie who wanted to stifle the new social conflicts generated by market society. They referred to these incipient conflicts as "the social question", and they argued that the solution was for the masses to have access to goods and services that the new market society and the state were not capable of supplying, in particular basic foods (free from the usual frauds) and a wide array of educational, cultural, and welfare services (sick pay, unemployment and death benefits, retirement and widowhood pensions), the lack of which bred social discontent. ${ }^{24}$

Like other mutual organizations, consumer cooperatives emerged in Great Britain in the mid-nineteenth century ${ }^{25}$ and expanded later to the rest of the continent, in the wake of industrialization and the labour organizations' change in attitude towards them. Initially, labour organizations were reluctant to lend their support to cooperatives because they believed that they contributed to the exploitation of workers, but, later, in light of their popularity, they encouraged them wholeheartedly. ${ }^{26}$

Figure 1 illustrates the process in several countries from 1900 to 1941 and presents the estimated social impact of cooperatives in these years and in 1914, as well

\footnotetext{
${ }^{22}$ Medina-Albaladejo and Pujol-Andreu, "Cooperativas consumo y niveles vida".

${ }^{23} \mathrm{Ibid}$.

${ }^{24}$ E.P. Thompson, The Making of the English Working Class (London, 1963); E.A. Wrigley, Continuity, Chance, and Change: The Character of the Industrial Revolution in England (Cambridge, 1990).

${ }^{25}$ Holyoake, The History of the Rochdale Pioneers; F. Müller, "The Consumer Co-operatives in Great Britain", in Brazda and Schediwy, Consumer Co-operatives in a Changing World, pp. 46-137, 53-55; Watts, "Building an Alternative Economic Network?", p. 156; Robertson, "Collective Strength and Mutual Aid".

${ }^{26}$ J. Brazda and R. Schediwy, "Introduction", in idem, Consumer Co-operatives in a Changing World, pp. 13-42, 14-16.
} 
(a) 1900

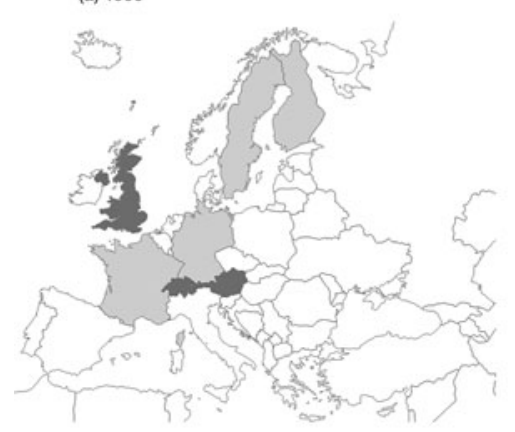

(b) 1914

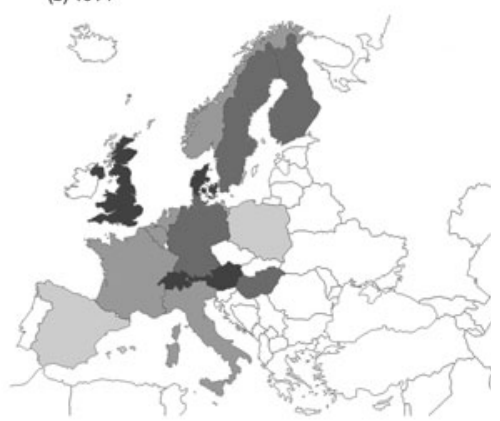

(c) $1937-1941$
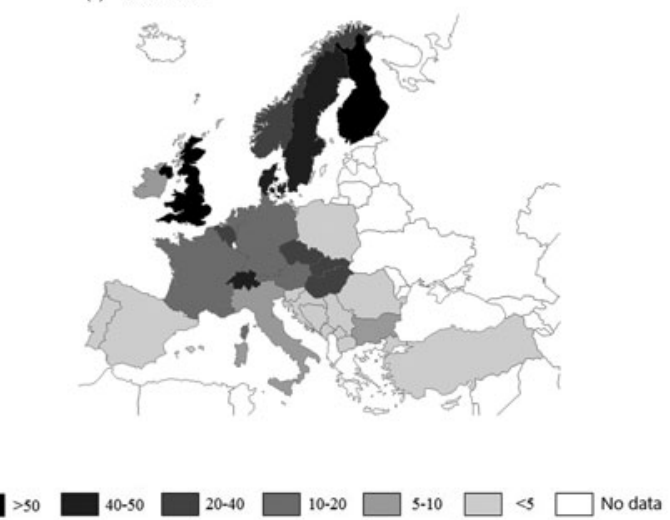

Figure 1. Social impact of consumer cooperatives in Europe, 1900-1941, as proportion of the population who were members of a cooperative and their relatives, assuming four-person households of which only one person was a member.

Sources: 1900: Cole, A Century of Co-operation, p. 371; H. Handschin, Der Verband Schweiz. Konsumvereine (VSK), 18901953 (Basel, 1954), p. 355; R. Blaich, "The Consumer Co-operatives in Austria", in Brazda and Schediwy, Consumer Co-operatives in a Changing World, pp. 900-1021, 906; E. Furlough, Consumer Cooperation in France: The Politics of Consumption: 1834-1930 (Ithaca, 1991), p. 76; J. Brazda, "The Consumer Co-Operatives in Germany", in Brazda and Schediwy, Consumer Co-operatives in a Changing World, pp. 141-226, 149; R. Schediwy, "The Consumer Co-Operatives in Sweden", in Brazda and Schediwy, Consumer Co-operatives in a Changing World, pp. 230-339, 239; R. Schediwy, "The Consumer Co-operatives in Finland", in Brazda and Schediwy, Consumer Co-operatives in a Changing World, pp. 573-670, 585; 1914: Gide, Consumers' Co-operative Societies, p. 49; 1937-1941: International Labour Office, Co-operative Organisations and Post-War Relief, p. 105; population data: A. Maddison, The World Economy (Paris, 2006).

as total population figures. We assume that all members were male heads of households. ${ }^{27}$ The relatives of members would also have benefited directly from the cooperatives.

\footnotetext{
${ }^{27}$ Medina-Albaladejo and Pujol-Andreu, "Cooperativas consumo y niveles vida"; Medina-Albaladejo, "Consumer Co-operatives in Spain". The cooperatives analysed in the present article confirm that most of the members of these institutions were men. The Cooperativa La Artesana had only thirty-nine female members out of a total of 720 in the period 1902-1937, i.e. 5.4 per cent. In other cooperatives the percentage of female members was similar: 10.5 per cent in La Formiga Mantinenca; 4.6 per cent in La Vanguardia Obrera; 3.7 per cent in Pau i Justícia; 2.2 per cent in El Respeto Mutuo; and 6.4 per cent in Cooperativa de Súria (see sources in Table 4). This is not to say that their role was unimportant in the operation of
} 
In 1900, consumer cooperatives were a significant phenomenon only in Great Britain, ${ }^{28}$ but the phenomenon spread widely afterwards and it became relevant in some countries prior to World War I. At this time, approximately twenty-five per cent of the British, Swiss, Danish, and Austrian populations benefited from the services provided by consumer cooperatives: twelve per cent in Germany, Sweden, and Finland; eight per cent in France, Italy, and Belgium; and six per cent in Norway and the Netherlands. In addition to this expansion, wider initiatives began to emerge, such as the International Cooperative Alliance (ICA), which was created in 1895.

During the following years, the scarcity of consumption goods caused by World War I and the economic instability of the interwar period increased the prestige and appeal of consumer cooperatives. If in 1914 they had 7 or 8 million members in Europe, by 1922 their membership had soared to 10 million, and by 1930 to 20 million. ${ }^{29}$ Between 1910 and 1920, membership in Great Britain increased from 2.5 to 4.5 million - impacting approximately forty per cent of the population. ${ }^{30}$ The expansion of cooperativism was also significant in Germany, France, Austria, Switzerland, Scandinavia, and Italy, in what has been labelled "the post-war spring of cooperativism". ${ }^{31}$

The pace of growth was especially uneven during the interwar period. In Germany, Austria, and Italy, National Socialists and fascists replaced these institutions with government-controlled ones, leading to a drop in the number of members. In other countries, however, the movement continued to grow quickly. In Great Britain, around 1940, cooperatives had almost 9 million members, impacting close to seventy per cent of the population. In Finland, the impact of cooperatives was similar to that in Great Britain; in Switzerland, Sweden, and Denmark they reached over forty per cent of the population. ${ }^{32}$ It is likely that in some of these countries, the impact of cooperatives was even greater because agrarian cooperatives were well developed, and many of these also acted as consumer cooperatives. ${ }^{33}$ For this reason, the International Labour Office estimated that 5 million should be added to the official tally of 20 million members before World War II. ${ }^{34}$

In short, by 1940 these organizations played an important role in Northern and Central Europe, and their activities reached between 80 and 100 million Europeans. This was a significant proportion of the population, and it is important that we reach a better understanding of how they affected the living conditions of their members.

\footnotetext{
cooperatives, as some studies of the British case have shown (Blaszak, "The Gendered Geography of the English Co-Operative Movement"; Gurney, "Redefining 'the Woman with the Basket").

${ }^{28}$ G.D.H. Cole, A Century of Co-operation (Oxford, 1944).

${ }^{29}$ C. Gide, Consumers Co-operative Societies (New York, 1922), p. 49; International Labour Office, Co-operative Organisations and Post-War Relief (Montreal, 1944), p. 105. See also Brazda and Schediwy, "Introduction", p. 17.

${ }^{30}$ Gide, Consumers Co-operative Societies, p. 50.

${ }^{31}$ Zamagni et al., Cooperazione consumo Italia, p. 224.

${ }^{32}$ International Labour Office, Co-operative Organisations and Post-War Relief, p. 105.

${ }^{33}$ There were also agrarian consumer cooperatives in Great Britain. See N. Mansfield, "Paternalistic Consumer Co-operatives in Rural England, 1870-1930", Rural History, 23:2 (2012), pp. 205-211.

${ }^{34}$ International Labour Office, Co-operative Organisations and Post-War Relief, p. 107.
} 


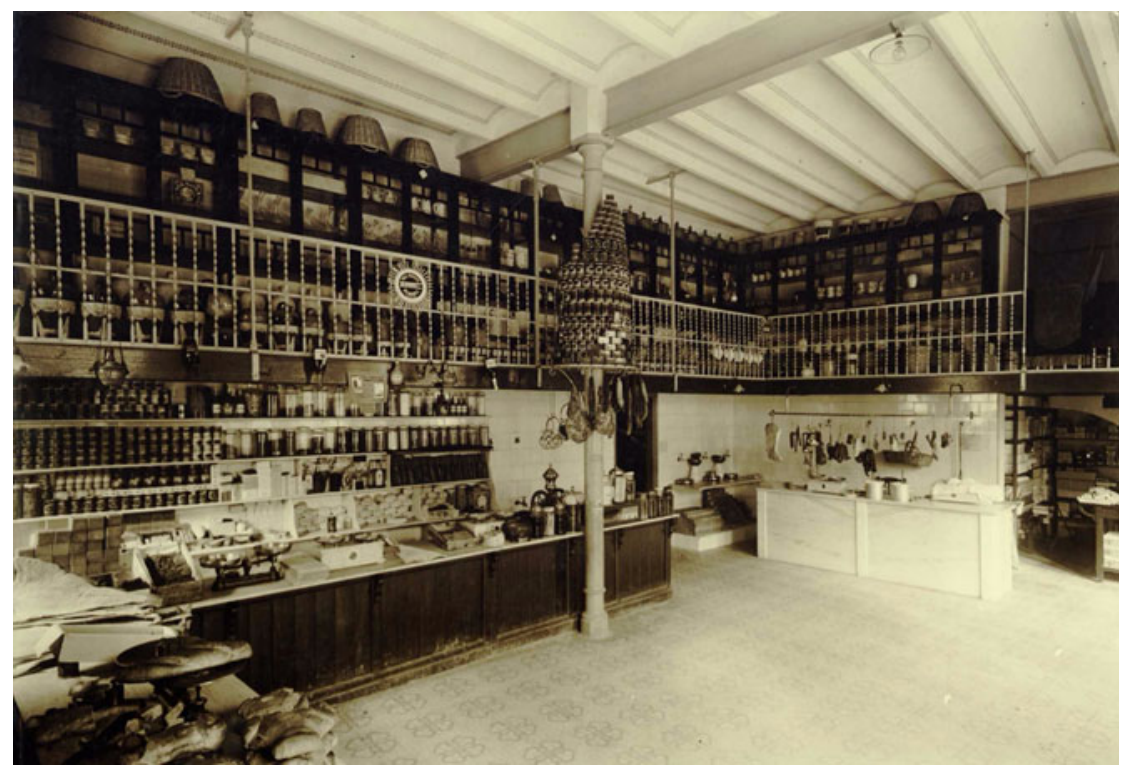

Figure 2. Grocery store of Cooperative La Flor de Mayo (branch no. 6) (Barcelona, Spain), 1923. Arxiu Nacional de Catalunya, ANC2-100-N-38, Sociedad Cooperativa Obrera de Ahorro y Consumo La Flor de Mayo.

In the following section, we shall focus on five cooperatives in the province of Barcelona and examine their impact on the diet and nutrition of their members' households.

\section{Food consumption and nutrition}

Previous studies suggest that, between 1898 and 1935, consumer cooperatives in Barcelona mostly stocked bread, flour, wheat, rice, legumes, olive oil, wine, pasta for soups, pork fat, and sugar; a few also sold eggs and salted fish (cod and herring). Later, they also began stocking coffee, chocolate, cold meats, and tinned food, i.e. energy-rich and easily stored foodstuffs (Figure 2), the commercialization of which did not demand complex infrastructures or specialized vendors. Fresh fish, meat, milk, fruit, and vegetables were sold only rarely. ${ }^{35}$

The data compiled from five cooperatives in the province of Barcelona with an aggregate membership of 203 in 1902 allow us to move further. The data are detailed, and precise estimates can be made of household-consumption figures. ${ }^{36}$ In all cases, members were forbidden from buying elsewhere the products that the cooperatives sold, and there were important incentives in place to ensure this, as we shall see in the final section.

\footnotetext{
${ }^{35}$ Medina-Albaladejo and Pujol-Andreu, "Cooperativas consumo y niveles vida".

${ }^{36}$ These data are based on statistical information on cooperatives compiled by Revista Cooperativa Catalana, the main publication issued by the principal Catalonian association of cooperatives in the early twentieth century. The data include the number of members of each cooperative, the foundation year, and total food sales in 1902. Revista Cooperativa Catalana, 49 (May 1903), p. 202.
} 
It is likely that members also consumed products purchased elsewhere, especially those products the cooperative did not offer. The problem this presents is not easy to resolve, and common to all the diets of the period analysed in the literature. Apparent consumption diets did not take into account food waste, the unequal distribution of food, and self-supply, which was probably significant during this period. Hospital diets do not consider food brought from outside. In addition, it is unclear to what extent diets described in the primary sources, such as medical topographies, were representative of the working population as a whole. Although these sources provide valuable information on environmental, nutritional, and medical conditions during this period, their observations concerning diets are subjective and based on personal observation, which they extrapolated to encompass wide social groups, rather than systematic surveys.

Table 1 presents the foodstuffs on offer, the quantities in which they were sold, and the daily consumption per member and household, based on an average family of four members (father, mother, and two children under fifteen; a total of 812 people). ${ }^{37}$ For the conversion of kilograms into calories, we used the coefficients published by Base de Datos Española de Composición de Alimentos (BEDCA), ${ }^{38}$ which takes into consideration the non-edible percentage of each foodstuff. ${ }^{39}$ The lack of contemporaneous estimates forces us to use current estimates, even if this could affect the results somewhat. This methodology is widely followed by studies on nutrient intake in the past. ${ }^{40}$

The dietary needs of all household members were not identical, however, and food would be unevenly distributed according to sex, age, height, weight, and activity. ${ }^{41}$

\footnotetext{
${ }^{37}$ Data on family structures in Spain in 1900 suggest that the average household comprised two adults and two children under fifteen (R. Nicolau, "Población, salud y actividad", in Carreras and Tafunell, Estadísticas Históricas de España, pp. 77-154, 145-146). To double-check this, we analysed the family structure of the members of the Cooperativa La Formiga Martinenca (Barcelona), whose records indicate the number of people living in the household at the time a member registered. The average household comprised 3.5 members. Registro de socios, 1904-1937, Archivo Municipal de Barcelona [hereafter, AMB], Sección Sant Martí de Provençals, Cooperativa La Formiga Martinenca, AMDSM3-190.

${ }^{38}$ Spanish Food Composition Database. Available at: http://www.bedca.net/bdpub/index.php; last accessed 27 July 2021.

${ }^{39}$ This database has been used by previous studies, including J.J. García Gómez, "El nivel de vida de los trabajadores de Alcoy. Salarios, nutrición y reforma sanitaria (1836-1913)", Investigaciones de Historia Económica-Economic History Research, 11 (2015), pp. 164-173; idem, and E.M. Trescastro López, "Transición nutricional, bienestar y salud. El caso de una ciudad industrial, Alcoy (1852-1928)", Dynamis, 37:2 (2017), pp. 389-411; X. Cussó, G. Gamboa, and J. Pujol-Andreu, "El estado nutritivo de la población española, 1860-2010. Una aproximación a las diferencias de género y generacionales", Nutrición Hospitalaria, 35 (2018), pp. 11-18.

${ }^{40}$ In recent years, this issue has been at the centre of an interesting debate. While some authors hold that contemporary conversion systems must be avoided, as they tend to overestimate nutrient intake (T. Logan, "The Transformation of Hunger: The Demand for Calories Past and Present", Journal of Economic History, 69:2 (2009), pp. 388-408; idem, "The Transformation of Hunger Revisited: Reply", Journal of Economic History, 75:2 (2015), pp. 526-530), others argue in favour of reliable conversion systems to compensate for the scarcity of primary sources (I. Gazeley, A. Newell, and M. Bezabih, "The Transformation of Hunger Revisited: Estimating Available Calories from the Budgets of Late Nineteenth-Century British Households", Journal of Economic History, 75:2 (2015), pp. 512-525).

${ }^{41} \mathrm{R}$. Floud et al., The Changing Body: Health, Nutrition, and Human Development in the Western World since 1700 (Cambridge, 2011), p. 46.
} 
Table 1. Consumption structure based on the products supplied by consumer cooperatives in Barcelona in the early twentieth century. ${ }^{(a)}$

\begin{tabular}{llcccc}
\hline Product & $\begin{array}{c}\text { Total } \\
\text { weight } \\
(\mathrm{kg})\end{array}$ & $\begin{array}{c}\text { Consumption per day } \\
\text { per person (g) }\end{array}$ & $\begin{array}{c}\text { Calories per } \\
\text { day per person }\end{array}$ & $\begin{array}{c}\text { Cost per } \\
\text { total }\end{array}$ & $\begin{array}{c}1,000 \\
\text { calories }\end{array}$ \\
\hline Red wine & 139,620 & 471 & 334.5 & 11.8 & 0.352 \\
\hline Olive oil & 14,863 & 50 & 444.8 & 15.6 & 0.169 \\
\hline Bread & 152,197 & 514 & $1,232.4$ & 43.3 & 0.175 \\
\hline Rice & 7,506 & 25 & 98 & 3.4 & 0.147 \\
\hline Pasta for soups & 4,960 & 17 & 59.1 & 2.1 & 0.283 \\
\hline Beans & 25,560 & 86 & 234.6 & 8.2 & 0.184 \\
\hline Pork fat & 15,172 & 51 & 340.4 & 12 & 0.376 \\
\hline Cod & 3,888 & 16 & 42.2 & 1.5 & 0.388 \\
\hline Sugar & 4,380 & 15 & 60.3 & 2.1 & 0.306 \\
\hline Total calories & & & 2,846 & & 0.227 \\
\hline Factor conver. ${ }^{\text {(b) }}$ & & & 3,711 & & \\
\hline Cal. cons. unit ${ }^{\text {(c) }}$ & & & & & \\
\hline
\end{tabular}

Notes:

(a) This includes data from La Mataronense (Mataró, Barcelona; 23 members), La Puertorriqueña (Mataró, Barcelona; 13 members), La Obrera Tianesa (Tiana, Barcelona; 95 members), La Unión (Premià de Mar, Barcelona; 37 members), and La Económica Masnouense (El Masnou, Barcelona; 38 members).

(b) An example of the calculation of the factor for converting to consumption per equivalent adult male can be found in Floud et al., The Changing Body, p. 46.

(c) Calories per consuming unit, or consumption per equivalent adult male aged 20-39 (consumption per capita divided by factor for converting consumption per equivalent adult male). See text.

Sources: Revista Cooperativa Catalana, 49 (May 1903), p. 202; Base de Datos Española de Composición de Alimentos (BEDCA). Available at: http://www.bedca.net/bdpub/index.php; last accessed 4 August 2021; Spanish population structure data, 1900: Dirección General de Instituto Geográfico y Estadístico, Censo de la población de España (Madrid, 1913); price data: Ayuntamiento de Barcelona, Anuario Estadístico de la Ciudad de Barcelona (Barcelona, 1902), pp. 528-530.

Some studies have demonstrated that this was, in fact, the case, and that Spanish women and children were not as well fed as adult males. ${ }^{42}$ In addition, we must bear in mind that the working classes were often forced to take physically demanding jobs, and men working moderately or highly demanding jobs needed between 2,800 and 3,500 calories per day, which was far above average. ${ }^{43}$ Most members of consumer cooperatives fitted this profile, ${ }^{44}$ and so, to standardize calorific intake by age and sex, calories per capita must be normalized to that of adult males aged 20-39, the "calories per consuming unit" method.

\footnotetext{
${ }^{42}$ C. Borderías, P. Pérez-Fuentes, and C. Sarasúa, "Gender Inequalities in Family Consumption: Spain 1850-1930", in T. Addabbo et al. (eds), Gender Inequalities: Households and the Production of Well-being in Modern Europe (Aldershot, 2010), pp. 179-195.

${ }^{43}$ Floud et al., The Changing Body, p. 169.

${ }^{44}$ Some of the cooperatives' records reflect this: the most common occupations were day labourers, bricklayers, tanners, miners, brickmakers, mechanics, and textile workers (see Table 4).
} 
Some conclusions can be drawn from Table 1. First, it confirms what we already know concerning the sort of products sold by these cooperatives. The cooperatives we are examining retailed only basic products (but not all of them). They specialized in bread, legumes, rice, pasta for soups, olive oil, cod, wine, sugar, and pork fat. Second, these products met their members' calorific needs. Considering daily consumption figures, the average calorific intake of a four-member household would be 2,846 calories, which is significantly higher than the published estimates for Spain in the early twentieth century $(2,404$ on average $) .{ }^{45}$ Finally, it is significant that cooperatives met the calorific needs of adult males aged 20-39. Calories per consuming unit rise to 3,711 per day, which is above the maximum requirement for males in highly demanding jobs. Allen's method, ${ }^{46}$ which estimates that the consumption of five-member households was equivalent to that of three adult males, leads to a similar conclusion (using this method, the daily intake of adult males would be 3,795 calories).

Tables 2 and 3 provide further information. They compare macro- and micronutrient consumption based on the products supplied by cooperatives and four model diets for the early twentieth century. The first two diet estimates are based on apparent consumption figures for a wide array of products, some of which were rarely accessible to the working classes (fruit, vegetables, poultry, milk, fresh fish, chocolate). The first one refers to Spain in general and was elaborated by Simpson using agricultural production and foreign trade data for 1897-1901. ${ }^{47}$ The second considers the products that entered Barcelona daily, according to the city council's records for 1902, and Nicolau and Pujol-Andreu's estimates of animal-based product consumption during this period. ${ }^{48}$ The other two model diets are real-consumption estimates. One reflects the diet of a labourer in Badalona, an industrial city near Barcelona, and was developed by a prestigious local doctor in $1903 .{ }^{49}$ The final one is based on the average diet in Barcelona's main hospital (Hospital Clínico), and it takes into consideration the hospital purchases of food and the number of patients and carers in $1909 .^{50}$ In order to homogenize the data, we use the same cal $/ \mathrm{kg}$ coefficients used for cooperatives (BEDCA database) and the minimum recommended micronutrient

\footnotetext{
${ }^{45}$ Cussó et al., "Estado nutritivo de la población española”, p. 15. Other authors have reached similar estimates for Spain in 1900 (2,622 calories per capita). M. González de Molina et al., "Crecimiento agrario en España y cambios en la oferta alimentaria, 1900-1933”, Historia Social, 80 (2014), pp. 157-183, 171. They all exceed the recommended dietary allowance (RDA), which for 1900 has been estimated as 2,274 calories per capita in Spain. These estimates take into consideration gender, age, birth rate, height, and environmental conditions. Cussó et al., "Estado nutritivo de la población española", p. 14.

${ }^{46} \mathrm{R}$. Allen, The British Industrial Revolution in Global Perspective (Cambridge, 2009).

${ }^{47}$ J. Simpson, "La producción agraria y el consumo español en el siglo XIX", Revista de Historia Económica - Journal of Iberian and Latin American Economic History, 7:2 (1989), pp. 355-388, 366-367.

${ }^{48}$ Ayuntamiento de Barcelona, Anuario Estadístico de la Ciudad de Barcelona (Barcelona, 1902), p. 527; J. Pujol-Andreu and R. Nicolau, "El consumo de proteínas animales en Barcelona entre las décadas de 1830 y 1930. Evolución y factores condicionantes", Investigaciones de Historia Económica - Economic History Research, 1:3 (2005), pp. 101-134.

${ }^{49}$ J. Tuixans i Pedragosa, Apuntes topográficos-médicos de Badalona (Barcelona, 1903).

${ }^{50}$ Elaborated by Roser Nicolau after Ayuntamiento de Barcelona, Anuario Estadístico de la Ciudad de Barcelona (Barcelona, 1906-1923).
} 
Table 2. Calorific intake and distribution in terms of food groups and macronutrients in the early twentieth century.

\begin{tabular}{|c|c|c|c|c|c|}
\hline & $\begin{array}{c}\text { Spain } \\
(1897-1901)\end{array}$ & $\begin{array}{l}\text { Barcelona } \\
\quad(1902)\end{array}$ & $\begin{array}{c}\text { Badalona } \\
\text { (1903) }\end{array}$ & Hospital (1909) & $\begin{array}{l}\text { Coops } \\
(1902)\end{array}$ \\
\hline $\begin{array}{l}\text { Total energy per capita } \\
\text { (calories) }\end{array}$ & 2,192 & 2,766 & $2,255^{(b)}$ & 2,537 & 2,846 \\
\hline $\begin{array}{l}\text { Consumption per equivalent } \\
\text { adult male aged } 20-39\end{array}$ & 2,858 & 3,606 & 2,940 & 3,308 & 3,711 \\
\hline Protein intake (grams) ${ }^{(a)}$ & 42.8 & 75.4 & 97.1 & 67.1 & 48 \\
\hline \multicolumn{6}{|c|}{ Energy distribution (food groups) (\%) } \\
\hline Wine and drinks & 7.2 & 7.5 & 16.9 & 5.2 & 11.8 \\
\hline Vegetal fat & 11.7 & 9.9 & 8.8 & 8.6 & 15.6 \\
\hline Cereals & 51.3 & 47 & 40.8 & 34.3 & 48.8 \\
\hline Legumes & 3.6 & 2.9 & 8.1 & 5 & 8.2 \\
\hline Potatoes, vegetables, and fruit & 12.7 & 5 & 6 & 5.9 & 0 \\
\hline Animal-based products & 9.7 & 11.9 & 7.7 & 36.1 & 12 \\
\hline Fish & 1.3 & 3.3 & 11.6 & 0.9 & 1.5 \\
\hline Colonial products ${ }^{(c)}$ & 2.5 & 12.5 & 0.1 & 4 & 2.1 \\
\hline \multicolumn{6}{|c|}{ Energy distribution (macronutrients) (\%) } \\
\hline Proteins & 9.5 & 13 & 18 & 14.6 & 9.3 \\
\hline Fats & 18.7 & 11.7 & 12 & 22.4 & 18.6 \\
\hline Carbohydrates & 67.0 & 70.4 & 57.3 & 59.1 & 63.2 \\
\hline Alcohol & 4.8 & 4.9 & 12.7 & 3.9 & 8.9 \\
\hline \multicolumn{6}{|c|}{ Distribution of proteins, according to source (vegetal or animal) (\%) } \\
\hline Plant-sourced protein & 68.2 & 47.2 & 38.4 & 36.1 & 76.5 \\
\hline Animal-sourced protein & 31.8 & 52.8 & 61.6 & 63.9 & 23.5 \\
\hline \multicolumn{6}{|c|}{ Distribution of fats, according to source (vegetal or animal) (\%) } \\
\hline Plant-sourced fats & 78.8 & 60 & 62.2 & 32.4 & 62.1 \\
\hline Animal-sourced fats & 21.2 & 40 & 37.8 & 67.6 & 37.9 \\
\hline
\end{tabular}

Notes:

(a) Maximum biological value proteins have been estimated for all food groups and diets, based on data provided by FAO.

(b) This diet corresponds to that of an average worker for the period, and so is a reflection of the consumption by an average male worker performing moderate or heavy physical labour. If the factor for converting to consumption per equivalent adult male presented in Table 1 is applied, we can estimate total energy consumed per capita at a national level.

(c) Sugar, coffee, chocolate.

Sources: Spain (1897-1901): Simpson, “La producción agraria y el consumo español”, pp. 366-367; Barcelona (1902): Ayuntamiento de Barcelona, Anuario Estadístico de la Ciudad de Barcelona (Barcelona, 1902), p. 527, Pujol-Andreu and Nicolau, "El consumo de proteínas animales en Barcelona", pp. 110, 113, 117; Hospital Clínico (Barcelona) (1909): elaborated by Roser Nicolau after Ayuntamiento de Barcelona, Anuario Estadístico de la Ciudad de Barcelona (Barcelona, 1906-1923); Badalona (1903): Tuixans i Pedragosa, Apuntes topográficos-médicos de Badalona, pp. 58-59; Cooperatives (1902): Revista Cooperativa Catalana, 49 (May 1903), p. 202; Base de Datos Española de Composición de Alimentos (BEDCA); data to calculate the factor for converting consumption per equivalent adult male: Floud et al., The Changing Body, p. 46; data on the maximum biological value of proteins: Food and Agriculture Organization of the United Nations (FAO), Amino-acid Content of Foods and Biological Data on Proteins (Rome, 1981). 
intake suggested by Moreiras and others, ${ }^{51}$ taking into consideration the age and gender structure of the population for the national averages. ${ }^{52}$

Based on all these estimates, it can be safely argued that the calorie and protein intake demands of cooperative members and their households were met (see protein and calorie figures in Table 3). In terms of calorie intake, a diet based on the foodstuffs sold by cooperatives was sufficient to provide well over the number of calories reflected in the model diets, considering both the consumption per capita of fourmember households and the consumption per capita of adult males (in this case, the figure clearly outstrips the 3,500 kcal/day maximum threshold established for heavy labour). On the other hand, in terms of the structure of macronutrient consumption all diets were very similar. As was the case for all the other diets, a diet based on the products sold by cooperatives had the following characteristics: a) most of the calorie intake came from the consumption of cereals (mainly bread; 48.8 per cent), vegetal fats (mainly olive oil; 15.6 per cent), wine (11.8 per cent), and pork fat (animal-based products; 12 per cent); and b) protein and fat intake came mainly from the consumption of vegetal products (76.5 and 62.1 per cent of total intake, respectively). Only in the diet provided by Hospital Clínico was the calorie, protein, and fat intake based mostly on the consumption of animal-based products, as hospital diets were heavily based on meat, milk, and eggs. This sort of diet must have been common in most hospitals.

This does not mean that the food sold by cooperatives provided a balanced diet. This is reflected in Table 3, which presents the excesses and shortcomings of cooperative diets and the four model diets in terms of micronutrient intake, using the average demand of the Spanish population in 1900. Although the products sold by cooperatives met the calorie and protein demands, in terms of micronutrients they fell way short of minimum requirements. Although this applies to all the model diets under consideration, the shortcomings of cooperative diets in this regard seem especially acute; the deficit in terms of vitamins (fruit and vegetables) and minerals such as calcium (milk and eggs) was especially severe. In contrast, cooperative diets were rich in highly calorific food, such as wine, vegetal fat (olive oil), and animal fat (pork fat). All diets are similar in terms of cereal and fish (mostly salted cod) consumption. It is thus reasonable to presume that cooperative members did not exclusively base their diet on the products they purchased from the organization although the consumption of products purchased elsewhere probably fell short of the recommended minimum, a phenomenon seen in the case of most of the population. In the early twentieth century, many micronutrients had yet to be identified, and some foodstuffs that were key in this regard, such as fresh fish, milk, fruit, and vegetables, were consumed only rarely by most of the population. ${ }^{53}$

\footnotetext{
${ }^{51}$ O. Moreiras et al., Tablas de composición de alimentos (Madrid, 2015).

${ }^{52}$ As with cooperatives, whenever necessary, wheat and flour have been converted to bread, assuming that $1 \mathrm{~kg}$ of wheat provides $700 \mathrm{~g}$ of flour, and that $1.83 \mathrm{~kg}$ of flour is needed to make $3 \mathrm{~kg}$ of bread; since coffee was sold as beans but drunk as an infusion, the resulting calorie intake is also an estimate.

${ }^{53}$ X. Cussó, "El estado nutritivo de la población española 1900-1970. Análisis de las necesidades y disponibilidades de nutrients", Historia Agraria, 36 (2005), pp. 329-358; X. Cussó and R. Garrabou, "La transición nutricional en la España contemporánea. Las variaciones en el consumo de pan, patatas y legumbres (1850-2000)", Investigaciones de Historia Económica - Economic History Research, 3:7 (2007),
} 
Table 3. Energy, protein, and micronutrient consumption in the early twentieth century compared with the recommended dietary allowance (RDA = 100).

\begin{tabular}{|c|c|c|c|c|c|}
\hline & $\begin{array}{c}\text { Spain } \\
(1897-1901)\end{array}$ & $\begin{array}{c}\text { Barcelona } \\
\text { (1902) }\end{array}$ & $\begin{array}{c}\text { Hospital } \\
\text { (1909) }\end{array}$ & $\begin{array}{c}\text { Badalona } \\
(1903)^{(a)}\end{array}$ & $\begin{array}{c}\text { Cooperatives } \\
(1902)\end{array}$ \\
\hline Energy (cal.) $)^{(b)}$ & 96 & 121 & 112 & 103 & 125 \\
\hline Proteins $(\mathrm{g})^{(\mathrm{b})}$ & 100 & 176 & 156 & 179 & 112 \\
\hline \multicolumn{6}{|l|}{ Vitamins } \\
\hline Vitamin A $(\mu \mathrm{g})$ & $\left(^{\star}\right) 26$ & $\left(^{*}\right) 13$ & $\left(^{\star}\right) 35$ & $\left({ }^{\star}\right) 4$ & $\left({ }^{\star}\right) 1$ \\
\hline Vitamin D $(\mu \mathrm{g})$ & $\left({ }^{\star}\right) 17$ & $\left(^{*}\right) 25$ & $\left(^{\star}\right) 12$ & $\left(^{\star}\right) 39$ & $\left({ }^{\star}\right) 4$ \\
\hline Vitamin E (mg) & 81 & $\left(^{*}\right) 64$ & $\left(^{*}\right) 50$ & $\left(^{\star}\right) 57$ & $\left(^{*}\right) 68$ \\
\hline Vitamin C (mg) & 111 & 81 & 82 & 81 & (*) 3 \\
\hline Thiamine (mg) & 109 & 125 & 114 & 109 & 105 \\
\hline Riboflavin (mg) & $\left(^{\star}\right) 66$ & 86 & 130 & $\left(^{\star}\right) 79$ & $\left(^{\star}\right) 41$ \\
\hline Niacin (mg) & 122 & 159 & 181 & 135 & 88 \\
\hline Vitamin B6 (mg) & 105 & 125 & 115 & 131 & $\left(^{*}\right) 73$ \\
\hline Folic acid $(\mu \mathrm{g})$ & $\left(^{\star}\right) 79$ & 117 & $\left(^{\star}\right) 79$ & 99 & 119 \\
\hline Vitamin B12 ( $\mu \mathrm{g})$ & 132 & 313 & 223 & 339 & $\left(^{*}\right) 39$ \\
\hline \multicolumn{6}{|l|}{ Minerals } \\
\hline Calcium (mg) & (*) 59 & $\left(^{\star}\right) 47$ & 98 & $\left(^{\star}\right) 48$ & $\left(^{\star}\right) 45$ \\
\hline Phosphorus (mg) & 131 & 205 & 206 & 237 & 158 \\
\hline Magnesium (mg) & 99 & 113 & 106 & 132 & 104 \\
\hline Iron (mg) & 144 & 163 & 127 & 227 & 146 \\
\hline Zinc (mg) & $\left(^{\star}\right) 52$ & 80 & 90 & $\left(^{\star}\right) 61$ & $\left(^{*}\right) 53$ \\
\hline lodine $(\mu \mathrm{g})$ & $\left(^{\star}\right) 61$ & $\left(^{\star}\right) 73$ & 97 & $\left(^{\star}\right) 62$ & $\left(^{\star}\right) 37$ \\
\hline Selenium $(\mu \mathrm{g})$ & 284 & 380 & 258 & 282 & 329 \\
\hline
\end{tabular}

\section{Notes:}

$\left({ }^{*}\right)$ Micronutrient intake below eighty per cent of recommended amount.

(a) Since this diet refers to an adult male labourer, the recommended dietary allowances used are not those established for the population in general for 1900, but those established for males aged ten or above.

(b) The minimum energy and protein requirements for the Spanish population in 1900, taking into account gender, age, birth rate, height, and environmental conditions, were 2,274 calories and 42.9 grams per day.

Sources: See Table 2; recommended dietary allowance (calories and proteins): Cussó et al., "Estado nutritivo de la población Española", pp. 11-18, 14; recommended dietary allowance (micronutrients): Moreiras et al., Tablas de composición de alimentos; Spanish population structure data, 1900: Dirección General de Instituto Geográfico y Estadístico, Censo de la población de España.

Apparent consumption-based diets are somewhat more balanced, but we should realize that they were estimated based on supply, and they ignore product loss and income and gender inequality. These diets cover micronutrient intake requirements better than the cooperative diet, but they still fall short of minimum requirements

pp. 69-100; J. Pujol-Andreu and X. Cussó, "La transición nutricional en Europa occidental, 1865-2000. Una nueva aproximación", Historia Social, 80 (2014), pp. 133-155; Cussó et al., "Estado nutritivo de la población española”. 
for some vitamins (owing to low fruit and vegetable consumption), calcium and zinc (owing to low milk consumption), and iodine (owing to low fish consumption). These shortcomings are shared by all the diets analysed. At any rate, apparent consumption-based diets do not represent the real diet of the working classes, as clearly reflected by the comparison with our other model diets.

The diet from Hospital Clínico must also be used with caution because the number of animal-based products included was clearly anomalous: it is the only one of the diets examined to reach the minimum requirements in terms of calcium intake. This makes sense considering that, at the time, milk was regarded more as medicine than food. ${ }^{54}$ Recent works have demonstrated that, in the second half of the nineteenth century, barely six per cent of the population of Barcelona drank cow's or goat's milk, so it seems fairly safe to suggest that it was excluded from the diet of the working classes. ${ }^{55}$

The model diet that corresponds closest to that of the working classes of Badalona is similar in many ways to the cooperative diet, which suggests that it is much closer to the real diet of these population groups than the diets based on apparent- and hospital-consumption data. In addition, it is based not on averages, but directly reflects the diet of real labourers. In this case, we must note the high levels of fish and alcohol (wine) consumption, which may be extrapolated to low-income groups in general during this period. ${ }^{56}$ Compared with adult male consumption equivalents, this diet is among the most hypocaloric for population groups faced with high physical demands, suggesting that the average diet for the working classes was insufficient, and that the hypercaloric foods sold by cooperatives may have contributed to mitigating this problem.

In conclusion, the diets offered by the consumer cooperatives were unbalanced but met the calorific needs of their members (low-income, manual workers with highly demanding jobs) with the basic products that they provided, which were affordable and easy to store.

\section{Cost of living, benefits, and other cooperative services}

The services provided by consumer cooperatives were not limited to food; they also contributed to improving the living standards and material well-being of their members. To quantify this, this section will analyse the living costs of member families, as well as the financial advantages of membership, in terms both of hard cash and of social, educational, and cultural services (Figure 3). ${ }^{57}$

\footnotetext{
${ }^{54}$ R. Nicolau-Nos, J. Pujol-Andreu, and I. Hernández, "Milk, Social Acceptance of a New Food in Europe: Catalonia, 19th-20th Centuries”, Dynamis, 30 (2010), pp. 119-139.

${ }^{55}$ I. Hernández-Adell, F. Muñoz-Pradas, and J. Pujol-Andreu, "A New Statistical Methodology for Evaluating the Diffusion of Milk in the Spanish Population: Consumer Groups and Milk Consumption, 1865-1981", Investigaciones en Historia Económica - Economic History Research, 15:1 (2019), pp. 23-37.

${ }^{56}$ Various sources from the late nineteenth and early twentieth centuries mention that workers in several Spanish regions spent between twenty and thirty per cent of their wages on wine and other alcoholic beverages. C. Borderías, P. Pérez-Fuentes, and C. Sarasúa, "La desigualdad en el consumo familiar. Diferencias de género en la España contemporánea (1850-1930)", Áreas, 33 (2014), pp. 105-120, 113-115.

${ }^{57}$ Robertson, "Collective Strength and Mutual Aid"; Jackson, "Cooperative Movement and the Education of Working Men and Women"; Robertson, "The Business of Leisure".
} 


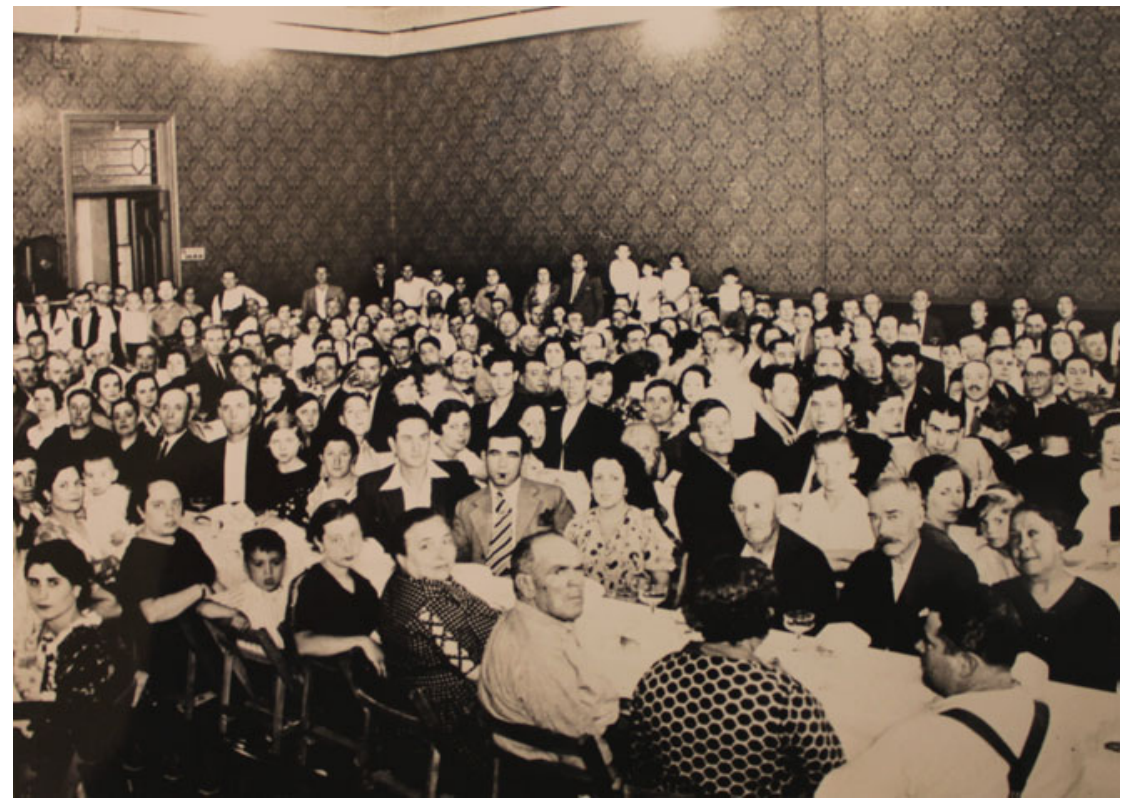

Figure 3. Fraternity meeting held at the headquarters of Cooperative La Flor de Mayo (Barcelona, Spain), 7 July 1935.

AMB, Sección Sant Martí de Provençals, Cooperativa La Flor de Mayo, I.1 ACT (FLO).

Most Catalonian consumer cooperatives followed the Rochdale model: they sold their products at market price and paid dividends to their members. ${ }^{58}$ However, the differences in the diets described above also involved differences in prices. That is, the advantages of membership were related not so much to the cost of the shopping basket but to the fact that members would have access to a calorie-rich diet appropriate for the high energy demands faced by manual labourers. The cost of the five model diets used has been calculated based on price information in Barcelona's municipal records for $1902 .{ }^{59}$ We have used a single source to avoid price differences during different periods. The diet corresponding to adult labourers in Badalona has not been considered because it does not reflect the whole household.

We have also calculated the daily cost of living per person (food, clothes and shoes, hygiene, fuel, and housing). According to Maluquer de Motes, food accounted for 65.7 per cent of daily expenses in Spain during this period. ${ }^{60}$ Multiplying this by 365 gives the annual cost of living per person; multiplying this by three gives the cost of living per household. We assume the two children in the four-member average household would require as much as one adult. ${ }^{61}$

\footnotetext{
${ }^{58}$ Medina-Albaladejo and Pujol-Andreu, "Cooperativas consumo y niveles vida"; Medina-Albaladejo, "Consumer Co-operatives in Spain".

${ }^{59}$ Ayuntamiento de Barcelona, Anuario Estadístico, pp. 528-529 (Barcelona, 1902).

${ }^{60} \mathrm{~J}$. Maluquer de Motes, "La inflación en España. Un índice de precios de consumo, 1830-2012", Estudios de Historia Económica, 64 (2013), pp. 40-41.

${ }^{61}$ Allen argues that consumption in a five-member family (three of them minors) would be equivalent to that of three adults. Allen, The British Industrial Revolution.
} 
Income is a problematic variable. Following other authors, it was assumed that most of the family income was earned by the male household head. ${ }^{62}$ The average wages of cooperative members has been estimated based on the socio-professional profile of the members of five cooperatives from Barcelona and the price information in the municipal records for 1902. Based on over 1,500 entries, the average daily wage has been established as 3.02 pesetas (Table 4). The number of working days is also problematic. Official sources suggest that the working week comprised five days, ${ }^{63}$ confirming a recent estimate of 280 working days per year in the construction sector; this estimate will be used, ${ }^{64}$ following Allen's standard. ${ }^{65}$ This gives an aggregate income of 845.6 pesetas per year. Based on this, the well-being rate has been calculated (daily wage divided by living costs) for both individuals and households.

The results are presented in Table 5. The cooperative diet is the cheapest of all our model diets - not because cooperatives undercut prices, but because of the structure of the diet, which was largely made up of low-cost, highly calorific products. As such, the cost of this diet per 1,000 calories was significantly lower than that of the other diets. This especially applies to bread, legumes, and olive oil, which were typical lowcost sources of proteins in Mediterranean Europe (see final column in Table 1). Concerning the welfare ratio, the cooperative diet yielded the highest values. Obviously, workers who were not cooperative members could access a similar diet at comparable prices. Cooperatives sold basic products that could be purchased by any retailer. However, the cooperative diet provided high calorie intake at low cost owing to the diet's own structure, while protecting cooperative members from one of the most widespread problems of this period: the adulteration of food in the market. ${ }^{66}$ More research is needed to ascertain if other geographical factors might also have played a role in this, and it is plausible to think that working-class neighbourhoods in which consumer cooperatives operated had worse food and basic household products distribution networks than other urban areas. In addition, as we shall see below, associates enjoyed important advantages over non-associates, such as the distribution of dividends and access to social and cultural services.

It can therefore be argued that cooperatives helped the working classes to maintain reasonably good living standards by distributing basic products. The resulting diet was not balanced, but met calorific demands and was affordable. It is interesting that they specialized in, inter alia, wine and olive oil, which, according to Nicolau

\footnotetext{
${ }^{62}$ García Gómez, "El nivel de vida de los trabajadores"; Borderías et al., "Gender Inequalities in Family Consumption".

${ }^{63}$ Comisión de Reformas Sociales, Reformas sociales, tomo III. Información oral y escrita practica en virtud de la Real Orden de 5 de diciembre de 1883. Valencia (Madrid, 1891). Other sources point out that male workers in Barcelona worked 285 days per year. Borderías et al., "Desigualdad consumo familiar", p. 115.

${ }^{64} \mathrm{M}$. García-Zuñiga, "Builders' Working Time in Eighteenth Century Madrid", Working Papers 0195, European Historical Economics Society (2020), p. 24; M. García-Zuñiga and E. López Losa, "Skills and Human Capital in Eighteenth-Century Spain: Wages and Working Lives in the Construction of the Royal Palace of Madrid (1737-1805)", Economic History Review, 74:3 (2021), pp. 691-720.

${ }^{65}$ R.C. Allen, "The Great Divergence in European Wages and Prices from the Middle Ages to the First World War", Explorations in Economic History, 38:4 (2001), pp. 411-447.

${ }^{66} \mathrm{X}$. Guillem-Llobat, De la cuina a la fàbrica. L'aliment industrial i el frau. El cas valencià en el context internacional (1850-1936) (Alicante, 2009).
} 
Table 4. Socio-professional profile and wages of cooperative members in Barcelona, ${ }^{(a)}$ 1894-1938.

\begin{tabular}{|c|c|c|c|}
\hline Trade & Observations & Wages (pesetas) & Percentage \\
\hline Day labourer & 1,205 & 2.8 & 75.5 \\
\hline Bricklayer & 107 & 4.3 & 6.7 \\
\hline Joiner & 60 & 4 & 3.8 \\
\hline Farmer & 46 & 2.9 & 2.9 \\
\hline Coppersmith & 22 & 3 & 1.4 \\
\hline Cart driver & 21 & 4.5 & 1.3 \\
\hline Dyer & 18 & 3.3 & 1.1 \\
\hline Painter & 13 & 4 & 0.8 \\
\hline Baker & 12 & 4 & 0.8 \\
\hline Boatswain & 12 & 5 & 0.8 \\
\hline Stoker & 9 & 4 & 0.6 \\
\hline Barber & 8 & 4 & 0.5 \\
\hline Leather worker & 7 & 3.3 & 0.4 \\
\hline Locksmith & 7 & 4 & 0.4 \\
\hline Glassmaker & 6 & 3.5 & 0.4 \\
\hline Other & 43 & - & 2.7 \\
\hline \multicolumn{2}{|c|}{ Total number of observations ${ }^{(b)}$} & 1,596 & \\
\hline \multicolumn{2}{|c|}{ Weighted average wage } & 3.02 & \\
\hline
\end{tabular}

Notes:

(a) The cooperatives examined include: La Vanguardia Obrera (Barcelona), La Formiga Martinenca (Barcelona), La Unió de Cooperadors de Súria (Súria, Barcelona), La Artesana (Barcelona), Pau i Justícia (Barcelona), and El Respeto Mutuo (L'Hospitalet de Llobregat, Barcelona).

(b) During the period under consideration, these cooperatives had a total of 2,688 members, but occupational data are available on only 2,015 . On the other hand, the public records do not always contain the necessary information concerning wages; therefore, only 1,249 entries could be used, comprising 62 per cent of members whose occupation is known, and 46.5 per cent of the total membership.

Sources: Ayuntamiento de Barcelona, Anuario Estadístico de la Ciudad de Barcelona, (Barcelona, 1902), pp. 557-562; Registro de Socios, 1894-1930, Archivo de la Fundació Roca i Galés, La Vanguardia Obrera; Registro de socios, 1904-1937, AMB, Archivo Sección Sant Martí de Provençals, Cooperativa La Formiga Martinenca, AMDSM3-190; Registro de Socios, 1916-1938, Archivo Municipal de Súria, Unió de Cooperadors de Súria; Registro de Socios, 1902-1937, AMB, Sección Sant Martí de Provençals, Cooperativa La Artesana; Registro de socios, 1900-1934, AMB, Sección Sant Martí de Provençals, Cooperativa Pau i Justícia, AMDSM3-191; Registro de socios, 1911-1937, Archivo Municipal de L'Hospitalet de Llobregat, Cooperativa El Respeto Mutuo, fondo núm. 505, caja 5.

and Pujol-Andreu, were comparatively cheaper in Barcelona than in other Spanish regions. ${ }^{67}$ In contrast, they did not specialize in legumes, fruit, and vegetables, which were comparatively expensive in the city. It seems natural to think that these organizations would offer cheaper prices to their members, but, in fact, these cooperatives operated not by undercutting prices but by focusing on offering basic low-

\footnotetext{
${ }^{67}$ R. Nicolau-Nos and J. Pujol-Andreu, "Variaciones regionales de los precios de consumo y de las dietas en España, en los inicios de la transición demográfica", Revista de Historia Económica - Journal of Iberian and Latin American Economic History, 24:3 (2006), pp. 521-553.
} 
Table 5. Living costs and welfare ratio based on four model diets in Spain in the late nineteenth and early twentieth centuries (pesetas).

\begin{tabular}{|c|c|c|c|c|c|c|c|}
\hline & $\begin{array}{c}\text { Price } \\
\text { diet }\end{array}$ & $\begin{array}{l}\text { Cost per } 1,000 \\
\text { calories }\end{array}$ & $\begin{array}{l}\text { Living } \\
\text { costs }\end{array}$ & $\begin{array}{l}\text { Annual living } \\
\text { costs }\end{array}$ & $\begin{array}{l}\text { Annual household living } \\
\text { costs }\end{array}$ & $\begin{array}{l}\text { Annual } \\
\text { income }\end{array}$ & $\begin{array}{l}\text { Welfare } \\
\text { ratio }\end{array}$ \\
\hline Spain & 0.79 & 0.358 & 1.20 & 436.5 & $1,309.5$ & 845.6 & 0.65 \\
\hline Barcelona & 1.02 & 0.369 & 1.55 & 567.1 & $1,701.2$ & 845.6 & 0.50 \\
\hline Hospital & 1.19 & 0.467 & 1.80 & 658.4 & $1,975.2$ & 845.6 & 0.43 \\
\hline Coops & 0.65 & 0.227 & 0.99 & 361.1 & $1,083.3$ & 845.6 & 0.78 \\
\hline
\end{tabular}

Sources: See Tables 2 and 4; Ayuntamiento de Barcelona, Anuario Estadístico de la Ciudad de Barcelona (Barcelona, 1902), pp. 528-530. 
cost, easily stored products that allowed their members to meet their households' basic calorific needs. Profits were made on all products sold, ${ }^{68}$ but the profit margin was smaller on low-cost products (wine, olive oil, cereal, legumes, cod, pork fat, and lard) than on non-basic products, such as animal-based products, coffee, chocolate, and spices. ${ }^{69}$

To conclude this analysis, we must examine how members used cooperatives and what benefits they obtained from them, in terms of both income and welfare. One should note that some of these organizations, especially the largest ones, forced their members to make their purchases from them, and imposed sanctions on those who did not. In smaller and newer cooperatives, in contrast, the only condition for membership was a minimum annual spend. ${ }^{70}$

In order to examine this issue, we have studied the records of the three cooperatives for which full chronological series exist: El Reloj (Barcelona); La Vanguardia Obrera (Barcelona); and Respeto Mutuo (L'Hospitalet de Llobregat, Barcelona). Figure 4 presents the average annual consumption by the members of these three cooperatives, as well as the average dividend paid, in both current and constant pesetas. For El Reloj, the data cover 1891 to 1919, for La Vanguardia Obrera 1909 to 1930, and for El Respeto Mutuo 1917 to 1935. In the periods for which there are data for more than one cooperative, the average is used. The average spending of members of cooperative El Reloj was 940 pesetas per year at the end of the nineteenth century, which is not far off our total annual income estimates presented in Table 5, based on the daily wages in Table 4 and on the total household living costs for cooperative diets. This suggests that cooperative members purchased most of their food from the cooperatives.

By observing the long-term evolution, we see that consumption levels remained fairly stable between the late nineteenth century and World War I, with little difference between real consumption and final consumption (as a result of almost nonexistent inflation). This allowed cooperative members to maintain their living standards. Things changed with the outbreak of World War I. Although Spain remained neutral during the war, it was not free from the inflationary processes that overtook

\footnotetext{
${ }^{68}$ Pre-tax profit margin (PPM): income before income tax/sales.

${ }^{69}$ Cooperativa La Rubinenca (Rubí, Barcelona) and L’Econòmica Palafrugellenca (Palafrugell, Girona). Medina-Albaladejo and Pujol-Andreu, "Cooperativas consumo y niveles vida"; A. Juanola i Boera, Cooperativa "L'Econòmica Palafrugellenca" (1865-1990) (Barcelona, 1990).

${ }^{70}$ Cooperative rules sanctioned members who did not reach a minimum spend, generally involving the loss of dividends and social benefits. In the event of recidivism, members could be expelled. There were few ways to prevent members purchasing goods outside the cooperative; they were generally limited to denunciations by other members. In any case, cooperative members had strong incentives to consume at least the regulated minimum in the cooperative, as this led to greater dividends and social benefits. For instance, the rules of cooperative La Formiga Martinenca established in 1924 that members "must get their supplies in the cooperative according to their family needs, which the Board will set out approximately at 100 pesetas per month" (article 2.6). The cooperative Pau i Justícia set a similar minimum in 1926 (500 pesetas per semester) for members not to lose their benefits, while cooperative La Flor de Mayo set out a minimum of 800 pesetas per year in 1928. Medina-Albaladejo and Pujol-Andreu, "Cooperativas consumo y niveles vida"; Estatutos, 1924, AMB, Sección Sant Martí de Provençals, Cooperativa La Formiga Martinenca, AMDSM3-190; Reglamento general, 1926, AMB, Sección Sant Martí de Provençals, Cooperativa Pau i Justícia, AMDSM3-191; Reglamento general, 1928, Archivo Nacional de Catalunya, Cooperativa La Flor de Mayo, ANC2-100.
} 


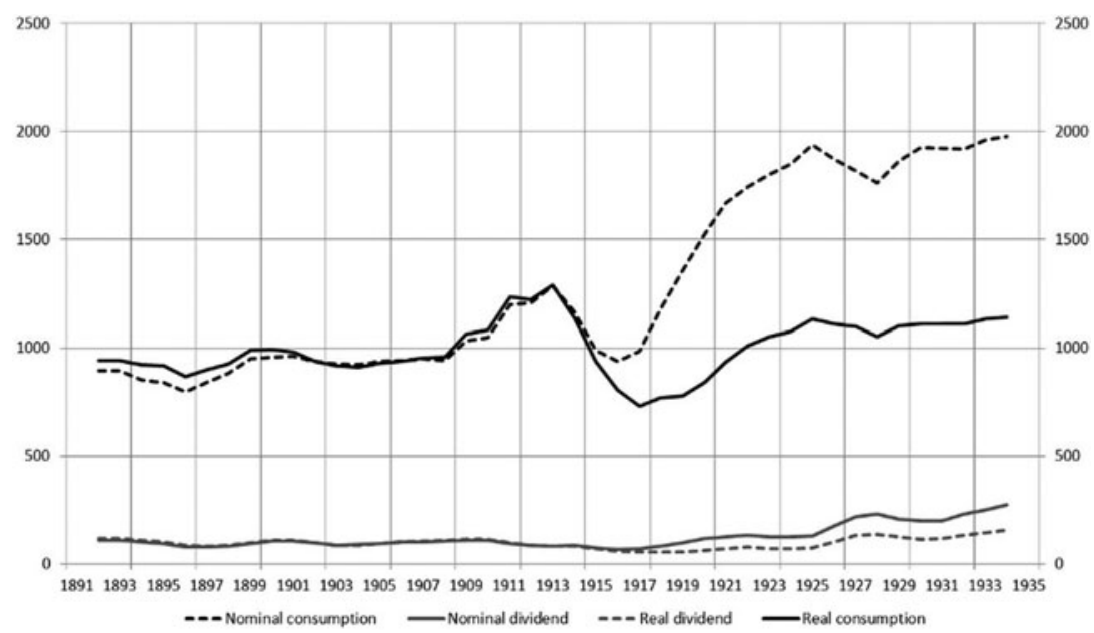

Figure 4. Consumption and dividend averages for the members of Cooperativa El Reloj, La Vanguardia Obrera, and El Respeto Mutuo, 1891-1935, using both current and constant pesetas from 1913 (three-year averages). Sources: Libro para las cuentas generales, 1891-1920, Archivo Nacional de Catalunya, Cooperativa El Reloj, ANC2-103; Libros de capital social, 1917-1935, Archivo Municipal de L'Hospitalet de Llobregat, Cooperativa El Respeto Mutuo, fondo núm.505, cajas 6, 7, 8; Estado de Cuentas, 1909-1933, Archivo del Gobierno Civil de la Provincia de Barcelona, La Vanguardia Obrera; data deflated by the Maluquer de Motes Consumer Price Index. Maluquer de Motes, "Consumo y precios", in Carreras and Tafunell, Estadísticas históricas de España, pp. 1247-1296, 1290-1291.

the continent and undermined the purchasing power and living standards of the working classes. Consumption and profits plummeted, and did not recover to pre-war levels until the 1920s.

The advantages of cooperative membership lay not in lower prices, but in the basic principle of the Rochdale model: members obtained benefits proportional to their purchases (what British cooperative members called the "divi"). By purchasing products from the organization, a member was given credit to spend on basic products in the following period; this essentially amounted to an extra form of income that could be spent only at the cooperative. Not only was the cooperative diet cheaper, it was also partially funded by membership and consumption, thus increasing workers' purchasing power and living standards.

What did this mean for the average cooperative member and his family? If a wage worker who was a member of cooperative El Reloj in 1900 had an average annual income of 845.6 pesetas (tables 4 and 5), and the average dividend paid by this society was 105.4 pesetas, the family's annual budget would have been 951 pesetas, i.e. a 12.5 per cent increase, covering most of the family's expenses of 1,083.3 pesetas, as calculated in Table 5 on the basis of the cooperative diet or the 957.3 pesetas that members consumed on average during that year, on food, clothes, shoes, and fuel (see Figure 4). This was in addition to the wife's potential income.

Not all cooperatives distributed the same proportion of their profits in dividends. As pointed out by Watts ${ }^{71}$ for the Scottish case, various models existed: one in the area of Edinburgh, mostly open to tertiary-sector employees, was characterized by

\footnotetext{
${ }^{71}$ Watts, "Building an Alternative Economic Network?”, pp. 157, 165.
} 
less solidarity, higher dividends, and competition between cooperatives. In the terminology of neoclassical cooperative theory, these cooperatives were dominated by the free-rider behaviour of opportunistic members who were concerned only with maximizing their personal gain. ${ }^{72}$ Under the other model, which prevailed in Glasgow's industrial areas, the membership were more committed to the cooperatives' ends: dividends were lower, but the educational, medical, and welfare services provided by the organizations were more varied.

Generally, cooperatives in Barcelona followed the second model, which is unsurprising given the industrial character of the area, where the textile sector was predominant. In 1912, there were eighty-one consumer cooperatives in Barcelona, nearly half of which distributed all or nearly all their profits (between eighty and 100 per cent) in the form of dividends. Nearly fifteen per cent of cooperatives distributed between sixty and sixty-five per cent of profits as dividends, and nearly twenty-five per cent of cooperatives between twenty and fifty per cent. Only eleven (13.6 per cent) cooperatives refrained from distributing dividends and put all profits into collective funds. ${ }^{73}$

Smaller and newer cooperatives provided their members with few services, and distributed a large proportion of profits as dividends. ${ }^{74}$ As these organizations grew, the distribution of dividends decreased and the provision of services such as sick pay, retirement pensions, and maternity leave (which neither the state, nor the market covered $)^{75}$ became increasingly important. They also operated as strike funds and provided educational and cultural services, such as theatre and cafes. Table 6 presents the average percentage of profits that a sample of cooperatives from Barcelona distributed as dividends, as well as the equivalence in basic products for members. We have established three periods: eleven cooperatives are examined for the first, and thirteen for the other two. The results indicate that, initially, approximately sixty per cent of profits were distributed as dividends, and that this percentage consistently decreased as the organizations consolidated. Meanwhile, initially, members received dividends of approximately six per cent, but this shrank to less than five per cent in the 1920s and 1930s. Although the cooperatives in Barcelona never came close to Watts' Scottish cooperatives (between nine and fifteen per cent during the same period) ${ }^{76}$ the increase in purchasing power was still significant.

\footnotetext{
${ }^{72}$ B. Ward, "The Firm in Illyria: Market Syndicalism", The American Economic Review, 48:4 (1958), pp. 566-589; J. Vanek, The General Theory of Labor-Managed Market Economies (Ithaca, NY, 1970).

${ }^{73}$ Museu Social de Barcelona, Anuari d'estadistica de Catalunya (Barcelona, 1912).

${ }^{74}$ The incipient nature of cooperativism in Barcelona is indicated by the small membership size. In 1915, average membership was barely above 100. Museu Social de Barcelona, Anuari d'estadistica.

${ }^{75}$ Social insurance was introduced in Spain later than in other European countries. Occupational accident insurance was adopted in 1900, retirement pensions in 1919, maternity leave in 1929, and unemployment benefits in 1931, while sick leave was not introduced until 1944, under Franco. Trade unions and mutual aid societies were the main source of social insurance for workers during the early decades of the twentieth century. S. Espuelas, "Los obstáculos al desarrollo de los seguros sociales en España antes de 1936. El caso del seguro de desempleo", Revista de Historia Industrial, 52 (2013), pp. 77-110, 77, 79; F. Largo Jiménez and J. Pujol-Andreu, "Desarrollo y crisis del mutualismo de trabajadores en España en el siglo XX. Nueva aproximación desde el capital social”, Scripta Nova, 20 (2016); J. Pons Pons and J. Silvestre Rodríguez (eds), Los orígenes del Estado del bienestar en España, 1900-1945. Los seguros de accidentes, vejez, desempleo y enfermedad (Zaragoza, 2010).

${ }^{76}$ Watts, "Building an Alternative Economic Network?", p. 157.
} 
Table 6. Average profits distributed as dividends and percentage of individual expenditure received as dividends, 1891-1935.

\begin{tabular}{lcc}
\hline Period & $\begin{array}{c}\text { \% of profits distributed } \\
\text { as dividends }\end{array}$ & $\begin{array}{c}\text { \% of expenditure received } \\
\text { in the form of dividends }\end{array}$ \\
\hline $1891-1910$ & 57.29 & 5.81 \\
\hline $1911-1920$ & 58.36 & 5.82 \\
\hline $1921-1935$ & 54.62 & 4.74 \\
\hline
\end{tabular}

Sources: Revista Cooperativa Catalana (1899-1905), La Económica Masnouense, La Central; El Cooperador Cooperativista (1905-1911), La Mercantil, La Equitativa, La Protectora Obrera, La Instructiva; El Cooperatista (1911-1915), La Obrera Andresense, La Moralidad Obrera, La Económica Bagurense, La Casa del Pueblo, La Constancia Sagrense, La Manresana; Cooperatismo (1915-1920), La Flor de Mayo, La Constancia Sagrense, La Manresana; Acción Cooperatista (1920-1935), La Constancia Sagrense, La Igualadina, La Hormiga, La Moral, La Puertorriqueña, La Económica, La Regeneradora Villanovesa; Estado de Cuentas, 1903, Archivo del Gobierno Civil de la Provincia de Barcelona [hereafter, AGCB], La Atrevida Martinense; Estado de Cuentas, 1909-1933, AGCB, La Vanguardia Obrera; Estado de Cuentas, 1914-1924, AGCB, La Fraternidad; Estado de Cuentas, 1904-1909, AGCB, La Igualitaria; Libro para las cuentas generales, 1891-1920, Archivo Nacional de Catalunya, Cooperativa El Reloj, ANC2-103; Inventarios y balances, 1905-1935, Archivo Nacional de Catalunya, Cooperativa La Rubinenca, 1-88, 14.2 (1); Libros de capital social, 1917-1935, Archivo Municipal de L'Hospitalet de Llobregat, Cooperativa El Respeto Mutuo, fondo núm.505, cajas 6, 7, 8; Inventarios y balances, 1916-1935, AMB, Sección Sant Martí de Provençals, Cooperativa Pau i Justícia, AMDSM3-191.

When the percentage of profits distributed as dividends decreased, the cooperatives allocated increasingly large amounts to collective funds for education, sick and disability pay, maternity leave, and retirement pensions. There is consensus that these programmes were one of the cooperatives' most significant contributions to the welfare of the working classes. Robertson also emphasized that British consumer cooperatives even became a source of credit during times of hardship. ${ }^{77}$ The percentage of profits allocated to each of these purposes varied from cooperative to cooperative, and Barcelona is no exception. Tables 7 and 8 present the welfare-related activity of a cooperative for 1909-1933. La Vanguardia Obrera began by distributing over sixty per cent of its profits as dividends, a percentage that had been reduced by half by the 1930s, as the funds allocated to education, sick and disability pay, retirement pensions, and reserves, as well as other purposes, such as covering transactions, increased. A similar trend may be detected in English cooperativism, for instance with the Lincoln Equitable Co-operative Industrial Society studied by Jackson, ${ }^{78}$ which, in 1870 , distributed 85.9 per cent of its profits as dividends, but only 63.5 per cent in 1900 and 38.1 per cent in 1920.

The impact of this welfare activity was considerable, and tended to grow over time. During the 1920s, it reached an average of twenty-two per cent of the cooperative's nearly 300 members; the number of days' sick pay received per member also grew. Old-age pensions were paid nearly all year round, and death benefits were fixed at 100 pesetas. It is obvious that members could not live on just their sick pay or old-age pension, especially given that the amounts paid remained stable despite the postwar inflation, but when they could not work this form of income alleviated their plight to some extent.

\footnotetext{
${ }^{77}$ Robertson, "Collective Strength and Mutual Aid".

${ }^{78}$ Jackson, "Cooperative Movement and the Education of Working Men and Women”, p. 34.
} 
Table 7. Distribution of profits of Cooperativa La Vanguardia Obrera, 1909-1933 (\%).

\begin{tabular}{|c|c|c|c|c|c|c|}
\hline & Dividends & Education & $\begin{array}{c}\text { Sick and } \\
\text { disability pay }\end{array}$ & Old age & Reserves & Other \\
\hline $1909-1913$ & 62.9 & 14.7 & 4.8 & 1 & 6 & 10.6 \\
\hline 1914-1918 & 47.7 & 15 & 15 & 5 & 5 & 12.3 \\
\hline $1919-1923$ & 31.7 & 15 & 15 & 6 & 5 & 27.3 \\
\hline $1924-1928$ & 29 & 15 & 15 & 15 & 5 & 21 \\
\hline $1929-1933$ & 29.6 & 15 & 15 & 15 & 5 & 20.4 \\
\hline
\end{tabular}

Sources: Estado de Cuentas, 1909-1933, Archivo del Gobierno Civil de la Provincia de Barcelona, la Vanguardia Obrera.

Table 8. Social expenditure of Cooperativa La Vanguardia Obrera, 1913-1927.

\begin{tabular}{lccc}
\hline & $1913-1917$ & 1918-1922 & 1923-1927 \\
\hline Percentage of members requiring assistance & 10.3 & 19.1 & 22 \\
\hline Average number of sick days per member & 46.6 & 65.8 & 66.7 \\
\hline Average number days on old-age pension per member & 298 & 304.1 & 276.5 \\
\hline Average daily sick pay (a) & 2.5 & 2.2 & 2.37 \\
\hline Average daily sick pay (b) & 2.3 & 1.3 & 1.4 \\
\hline Average daily old-age pension & 1 & 1 & 1.2 \\
\hline Death benefit & 100 & 100 & 100 \\
\hline
\end{tabular}

Notes: (a) current pesetas; (b) constant pesetas, 1913.

Sources: Estado de Cuentas, 1913-1933, Archivo del Gobierno Civil de la Provincia de Barcelona, la Vanguardia Obrera; data on average price per day and average quantity received (illness) deflated by the Maluquer de Motes Consumer Price Index; J. Maluquer de Motes, "Consumo y precios", in Carreras and Tafunell, Estadísticas históricas de España, pp. 12471296, 1290-1291.

\section{Conclusion}

We have tried to emphasize the role played by social economy and institutions for collective action, such as consumer cooperatives, in the evolution of the living standards of the working classes during industrialization in the nineteenth and twentieth centuries. They made food more accessible to the working classes and provided welfare services not provided by either the state or the market.

European consumer cooperatives, which were mostly oriented towards the working classes, became widespread in such countries as Great Britain, Switzerland, Germany, France, and Italy, as well as in Scandinavia. Their impact on living standards was substantial; they made basic products and services (food, clothing, shoes, hygienic products, housing) more accessible, while providing welfare and educational, recreational, and cultural services (Figure 5). The present article aimed to quantify this impact based on the example of Barcelona, the heart of the Spanish textile industry.

Our first conclusion is that consumer cooperatives met their members' calorific needs - although their diet was unbalanced - through affordable and easily stored 


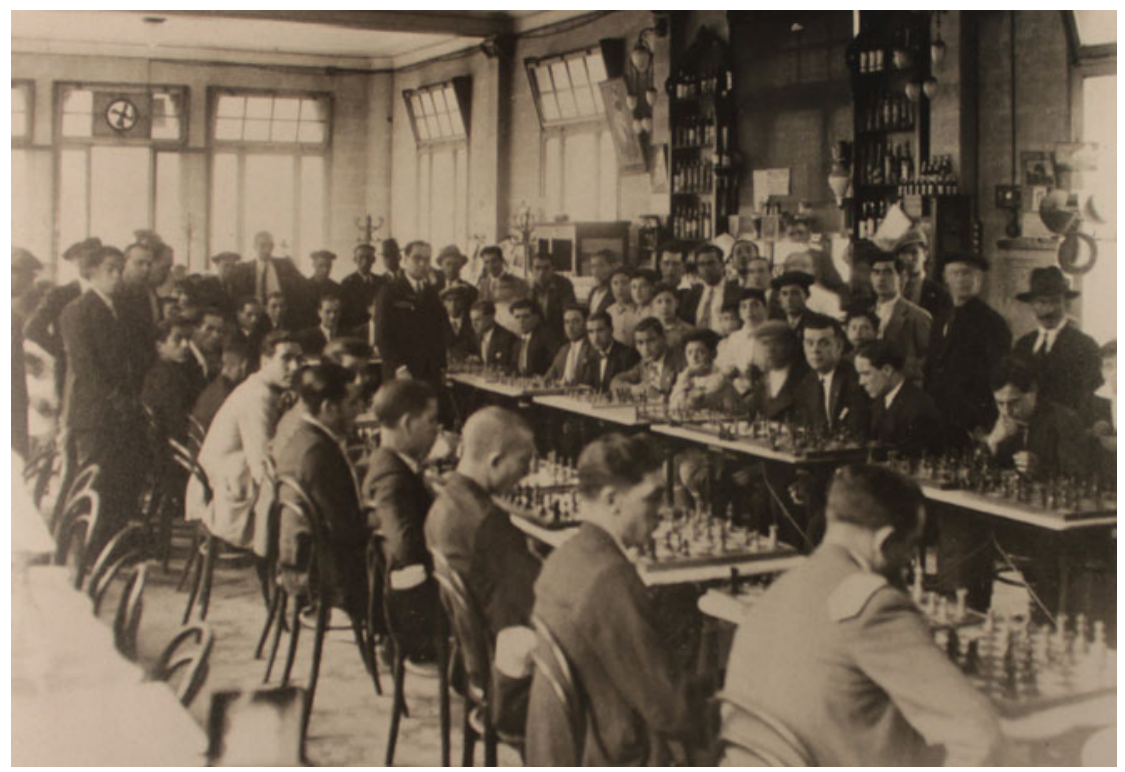

Figure 5. Simultaneous chess game at Cooperative La Constancia (Barcelona, Spain), c.1930. AMB, Sección Sant Martí de Provençals, I.1.1 (CONS), Cooperativa La Constancia.

basic products. Cereals (bread), wine, vegetal fat (olive oil), and animal fat (pork fat) were the basis of an unbalanced diet that did not meet many basic nutritional requirements (vitamins and minerals), but which did meet the calorific needs even of workers carrying out physically demanding jobs.

These cooperatives followed the Rochdale model: they sold their products at market prices and distributed their profits as dividends (calculated as a proportion of the members' spend), allowing members to cover between five and ten per cent of their expenses through the receipt of these dividends. The advantage of membership was not cheaper prices, but the dividends and the structure of the diet that the cooperative offered: low-cost, highly calorific products that fitted well with the purchasing power and energy needs of manual labourers. This allowed members to maintain reasonable living standards while enjoying services that would have been otherwise unobtainable: education; culture; leisure (theatres, cafes); sick pay; maternity leave; disability pay; credit; and strike funds.

The role of consumer cooperatives deserves more attention than it has received to date because they hold one of the keys to understanding the living standards of lowincome social groups in Europe during the second half of the nineteenth century and the opening decades of the twentieth. Future research should examine this issue further, for instance by focusing on similar organizations in other countries, comparing data, and reaching more general conclusions. It would also be interesting to investigate the role played by these collective action institutions in the changes undergone in dietary habits among the working classes within the framework of the European nutritional transition; consumption cooperatives may have facilitated access to new 
foodstuffs, contributing to their dissemination among low-income social groups. Another issue that should be studied further is the policies followed by these institutions during periods of high inflation - whether, for instance, they used their pricing policies to buffer the impact of rising prices upon the working classes. We also need to study the welfare services provided by these institutions in more detail, and what sort of impact these had on the lives of their members.

Supplementary material. The supplementary material for this article can be found at https://doi.org/10. $1017 /$ S0020859021000481

Acknowledgements. This work was supported by the Ministerio de Ciencia e Innovación (Spain), Projects HAR2016-76814-C2-1-P, PID2019-109336GB-I00 and PID2020-113793GB-I00 (AEI/FEDER, EU), and by Generalitat Valenciana (Spain) (Project PROMETEO/2020/083). We are grateful to Salvador Calatayud for his comments and suggestions. An earlier version of this work was presented at the Spanish Economic History Association Conference, held at the Universidad de Salamanca (Spain) in September 2017, and at the Economic and Social History Seminar (online), organized by the Universidad de la República (Uruguay) in July 2020. The authors would like to thank the participants for their comments and suggestions. This article has also benefited from the comments of the journal's editor and referees. All errors remain our own.

Cite this article: Francisco J. Medina-Albaladejo and Josep Pujol-Andreu. Social Economy and Living Standards: Consumer Cooperatives in Barcelona, 1891-1935. International Review of Social History, 67:2 (2022), pp. 317-342. https://doi.org/10.1017/S0020859021000481 